\title{
Ethical Sensitivity and The Perception of Accounting Students: Is the Love of Money and Greed the Root of Unethical Attitudes?
}

\author{
Aisa Tri Agustini* \\ Faculty of Economics and Business, University of Jember, 68121, Jember, East Java, Indonesia
}

\begin{abstract}
Objective - This research aims to investigate the influence of the love of money and greed on the individual's ethical sensitivity.

Methodology/Technique - The samples used are 50 students of accounting from Jember University. Path analysis is used to test the hypotheses.

Findings - The results show that there is an influence of the Love of Money on Greed. Theoretically, when one has fulfilled one's primary needs, one is able to survive. But human beings are not easily satisfied thus, they would always want to gain more. A person who loves money would be glad when he/she owns money since the person thinks that money can give him/her the comforts of life and the money that he/she has, can be used in whatever way he/she prefers. Novelty - Unlike previous studies, this study looks at the topic from the Islamic perspective.

Type of Paper: Review
\end{abstract}

Keywords: Accounting; Love of Money; Greed; Ethical Sensitivity; Indonesia.

JEL Classification: I21, M41.

\section{Introduction}

An ethical attitude is one of the important things that can influence the reputation of an individual or community. It is often related to the belief of one's professionalism. However, there are still many cases of unethical attitudes affecting the individual him/herself or the organization which he/she belongs to. The example of the tax peculation done by Gayus Tambunan shows how it had caused the country to suffer much losses, a total of at least $\mathrm{Rp} 570.9$ million. In western countries, the destruction of big companies like Enron and Worldcome illustrates how the poor implementation of the professionalism of accountants had led to the damage (Robertson, 2008). These examples, as cases of poor management of accounting professionalism, can decrease the trust of the society on the professionalism of accountants in general.

The ethics of behavior is often a dilemma for human beings as human beings are governed by basic negative characters such as the love of money and greed. This idea is supported by Luna-Arocas and Tang (2004) who mention that the love of money can predict and control a person's unethical attitudes. This is because the love

\footnotetext{
* Paper Info: Received: September 4, 2016

Accepted: December 3, 2016

* Corresponding author:

E-mail: aisa.agustini@gmail.com

Affiliation: Faculty of Economics and Business, University of Jember, Indonesia
} 
of money can influence a person's satisfaction of work and then lead him/her to participate in unethical acts or behavior. Luna-Arocas and Tang (2004) and Tang and Chiu (2003) explain that some general beliefs state that the love of money is the root of a crime and that this behavior is closely related to the greed concept (Sloan, 2002) which can drive an individual to collect as much money as possible and while doing that, the individual is often motivated to behave unethically.

Greed is a basic human characteristic that causes one to become dissatisfied with something that has been achieved by desiring to want better or higher achievements. While this is seen as related to greed (Tang \& Chiu, 2003), Chen and Tang (2006) believe that the relation can lead to unethical behaviors. Mastracchio (2005) explain that in accounting, having an awareness of the need to practice ethical attitudes ought to start from the accounting curriculum, long before a person enters the accounting profession. In this regard, students of accounting need to gather enough perspectives or views of the sensitivity towards ethical attitudes. Clikemen and Henning (2000) suggest that one of the purposes of the accounting education is to introduce students to values and ethical standards in the accounting profession. Accounting students are candidates of the public accounting profession who will work with money in the future Thus, taking an insight into the ethical perception of accounting students is a starting point to improve the ethical sensitivity of accounting students as candidates of the public accounting profession. In doing so, it is hoped that the results of the research can be used as consideration to evaluate whether an ethics course is necessary as such concepts can minimize corruption and fund deviations which tend to happen quite often recently. This research will thus empirically test the influence of the Love of Money and Greed as the basic character of human being towards the ethical sensitivity of an individual. In that regard, it aims to answer the question: Is the Love of money and Greed the root of unethical attitudes demonstrated by public accountants?

\section{Literature Review}

\subsection{Ethics and Ethical Sensitivity}

Wittmer $(1992,2005)$ defines ethical sensitivity as the relativity of awareness in the ethical dimension. Ethics came from the Greek ethos (character), personality or custom. As a subject, ethics will have something to do with the concept owned by an individual or group to assess whether his/her or their attitude is right or wrong, good or bad. Ethics can also be called the self control of an individual in behaving according to each individual's ethical code. The ethical attitude of a professional accountant is very important for the status determination and the professional credibility of an individual in the accounting profession (Chan \& Leung, 2006). Students of accounting, as future candidates of the public accounting profession also have big roles to play in carrying the ethical professionalism of an accountant. A professional accountant needs to develop his/her ethical attitude in his/her early career, long before he/she plunges him/herself into the profession. Such knowledge about the importance of ethical attitude must be disseminated as it is very important.

The ethical attitude practiced by a professional is influenced by the sensitivity of the individual and that attitude will then influence the individual's work performance when he/she becomes a professional accountant. The important factor in determining an individual's ethical attitude is to see whether or not the individual carries the awareness that he/she is a moral agent. Such kind of awareness can be observed from the ability he/she makes decisions. This is then called ethical sensitivity.

\subsection{The Love of Money and Greed}

Since human beings cannot be satisfied, it is their nature to want more. For example, when someone earns a certain amount of salary he/she has the expectation of getting more money or a higher salary through time and with this, the individual also expects to achieve bigger targets. This is termed as Gossen Law, a natural law owned by every individual. To elaborate, when a person is bored with what he/she has achieved, especially when it is through a monotonous routine, he/she strives for something else. This basic character can lead an 
individual to the desire of wanting more and bigger things than what he/she currently has and the more the craving is, the more the drive to look for the money or target.

Rationally, money is very crucial for people to fulfill their needs and it is rational when the love of money leads to unethical attitudes within an organization or company. Sloan (2002) sees the love of money as a wanting of money or greed, apart from their daily needs. Tang et al. (2005) add that the love of money is an individual's behavior towards money. It is hard to deny that money is very important for our daily needs so it can be very sensitive and hard to earn. Herzberg (1987) in Tang and Chiu (2003) explains that money is a motivator for some people while others call it the hygiene factor. Furnham and Argyle (1998) state that the love of money is like obsession because when the desire builds up, the person becomes really obsessed with everything about money.

The development of the millennium seems to give freedom to an individual to achieve the highest satisfaction, in fact, even satisfaction seems unlimited. Islam explains that the love of money is called Al Wahn. This is explained from HR.Abu Dawud and Ahmad, Rasulullah Shallallahu 'Alaihi Wasallam:

"Almost the people (the unbeliever or infidel) approach you from every direction, like the way they face food on a plate." Then someone asked, "Say it Prophet, will we be have little at that time?" He said, "You have a lot. But you are like rubbish carried by the rain. Allah will erase your fear of your enemies and give you 'wahn'." Then someone asked, "What's wahn?" The Prophet said, "The love of money and the fear of death." (HR. Abu Dawud and Ahmad)

In this context, wahn is a disease which an individual or a community suffers from. This disease leads people to suffer shellacking and indignity. The statement above implies that human beings are greedy for world pleasures. Besides this implication, Prophet Muhammad also states, based on Ibnu 'Abbas who heard the prophet said:

"If human beings are given two valleys full of wealth, they will want the third valley. The only thing that can satisfy their stomachs are the ground. Allah will accept the repent for those who ask for it." (HR. Bukhari number. 6436)

These statements suggest that human beings have greed for wealth and human beings are never satisfied with what they have but Allah actually tests them by giving them wealth and then putting them to face that so that human beings can increase their creed.

\subsection{Hypothesis Development}

According to Gossen Law, there is barely an individual who is never bored with what he/she has achieved, especially when it is related to money. Based on the fact that the love of money is a basic instinct of human beings (Sloan, 2002) and that the love of money principles are very closely related to the concept of greed (Tang and Chiu, 2003) and that this can lead to unethical attitudes (Chen \& Tang, 2006), the individual will thus, attempt very hard, to find a way to gain money continuously. The hypothesis that will be tested here is as follows:

Hypothesis 1: The love of money will positively influence greed

Lea and Webley (2006) mention that the function of money is not only as a means of exchange but also as drugs. They further explain that money plays an important role in satisfying human beings' biological and psychological needs. Psychologically, money makes someone addicted. Like drugs, money is strong, addictive and can be a motivator to create dissatisfaction. This will then lead to bad behavior like being a workaholic, gambling, consumerism, and unethical attitudes. (Tang et al., 2006). If someone loves money, he/she will seek for money and tend to do anything in any way to get much more money, both ethically and unethically. On the 
other hand, someone who does not value money much will not be so aggressive in getting more money. The hypothesis that will be tested here is as follows:

Hypothesis 2: Greed will negatively influence the individual's ethical sensitivity

Elias (2009) tested the relation between the love of money with ethical perceptions. When linked, they will create a negative relation. A research conducted by Tang and Chiu (2003) notes that the money ethics of an individual can create a significant and direct influence on unethical attitudes. Every human being needs money to survive but it does not just function as a means of exchange but also as an agent to acquire other materials or substances, addictive like drugs (Lea \& Webley, 2005). It was noted that money plays an important role in satisfying human being's basic needs thus, money is a biological need but as human beings' desires are insatiable, money can also affect human thoughts psychologically. Becoming addicted to money, the person can become so obsessed with it that that it can be a motivator creating dissatisfaction. When this occurs, the individual involved may turn to bad behavior such as working harder and spending more time to earn more money. As mentioned above, human beings can also resort to other illegal means to acquire more money such as gambling or indirectly, turn to consumerism hence, the manifestation of unethical attitudes. Most people need a lot of money to gain financial welfare like the way a drug addict needs higher doses to be high. As a means of exchange, money is never hated by anyone. However, the irrational love of money may influence the individual's ethical sensitivity.

The existence of money has been negatively judged by other researchers who think that money contributes negatively to its owners. Vohs et al. (2006) in their literature explains that money can increase independence where people have the choice to be free from depending on other people thereby, decreasing the feeling of dependence on other people. When this occurs, the person may stop asking for help from other people and he/she may even resort to helping other people. When an individual values money highly, he/she tends to become more private, selfish, socially isolated and sometimes even psychologically stressful. He/she will also be less open to other people, have low happiness, suffer from mental and physical illness, care less for other people and so possess low humanism and spirituality as compared to those who value money less highly (Kasser, 2002; Tang, 2006). The hypothesis that will be tested here is thus as follows:

Hypothesis 3: The love of money will negatively affect ethical sensitivity

\section{Research Method}

This research will use questionnaires as the main instrument to collect data. The questionnaires will be given directly to the respondents. This research is a causal study where the researcher expects to find the cause of sensitivity of the individual in order to evaluate it as high or low. This is done by applying Cross Sectional data which were extracted from 50 students in their fifth semester. The survey was conducted by distributing questionnaires to students of accounting at the Accounting Department of the Economic Faculty, Jember University. This is because the students of accounting are the candidates of the public accounting profession like those in their profession currently where high ethical sensitivity is necessary. The sample collection technique is thus based on purposive sampling.

\subsection{Variable Measurement}

\section{a) The Love of Money}

The measurement of the love of money will be measured by Tang et al.'s $(2002,2003)$ scale which consists of four different factors - motivation, success, the importance of money and wealth. As was explained previously, the love of money holds the view that money is a motivation that can represent someone's success, thus, the love of money is necessary for someone to be rich. That scale is connected to the theory of the love 
of money which attempts to measure someone's subjectivity about money. In that theory, the love of money will be measured by using Money Ethics Scale (MES) which was developed by Tang (2003). This scale measures how someone values money. Mitchell and Mickel (1999) in Charismawati and Yuyetta (2011) prescribe MES as the best survey to measure attitude towards money. In this research, respondents noted their agreement or disagreement by using the Likert Scale 5.0 or every person's statement at 7.0, with 1 (disagree very much) to 5 (agree a lot) and separated score for every factor is counted.

b) Greed

In this research, greed is closely related to how an individual wants to gain higher satisfaction. This obsession may lead an individual to higher greed. The measurement for greed is done by using the Money Beliefs and Behavior Scale modified by Furnham and Argyle (1998). This scale is formed by 14 selected questions equipped with the Likert Scale 5.0 or every person's statement at 5, with 1 (disagree very much) to 5 (agree a lot). The questionnaire used in this research does not include all the questions noted in the original instrument due to adjustments made to the sample and the topic used. From 6 of the original scale of Money Beliefs and Behavior Scale, five scales encompassing: obsession, retention, effort/ability, security and inadequacy will be used.

\section{c) Ethical Sensitivity}

Ethical sensitivity is the ability to be aware of ethical values in a certain decision making. Ethical sensitivity is measured by modifying the ethical sensitivity scenario of Shaub et al. (1993) namely the failure of an accountant in completing the job on time, the use of office hours for doing self-important matters, and the subordinate judgement of an accountant in relation with accounting principles. Likert Scale 1 until 7 is used to show the response and sensitivity criteria (1 - disagree very much until 7 - agree a lot). The higher the scale is, the higher the ethical sensitivity will be.

\subsection{Data Analysis Method}

The data analysis technique used in this research is Path Analysis which is the expansion of multiple linear regression analysis that tests causality among variables (Ghozali, 2012). Path Analysis is used to explain the relation pattern among variables in order to know the direct or indirect influence of a set of free variables (eksogen) on bound variables (endogen). This research will test the direct and indirect relation of the love of money with individual sensitivity through individual greed. The research framework that can show the relation among variables is as noted in Figure 1.

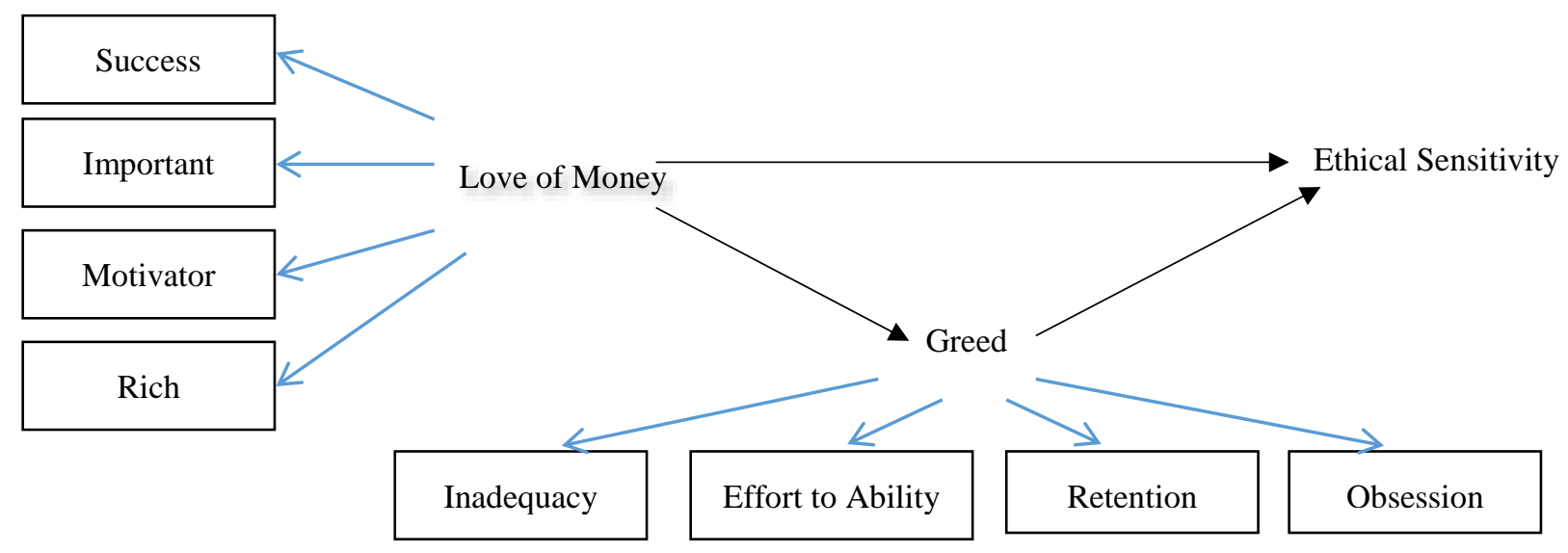

Figure 1. Research Framework 
Based on the statistical test noted in the first model testing the effect of love of money on greed of the students, the result observed are as follows:

Table 1. The effect of Love of Money on Greed

\begin{tabular}{|c|c|c|c|c|}
\hline $\mathrm{n}=100$ & $\begin{array}{c}\text { Standardized } \\
\text { Coefficients }(\beta)\end{array}$ & t-score & Sig.t & Description \\
\hline LOM & 0,259 & 2,651 & $0,009^{* * *}$ & Sig. \\
\hline
\end{tabular}

Sources: Secondary data was processed using existing SPSS

This result indicates that the love of money has a positive effect that is statistically significant to greed at level $\alpha=5 \%(\mathrm{t}=2,651, \mathrm{p}$-value $=0,009)$. This indicates that hypothesis 1 is supported. The second model of this research is the effect of the love of money and greed on ethical sensitivity. Based on statistical test the results are presented in Table 2 .

Table 2. The Effect of Love of Money and Greed on Ethical Sensitivity

\begin{tabular}{|c|c|c|c|c|}
\hline $\mathrm{n}=100$ & $\begin{array}{c}\text { Standardized } \\
\text { Coefficients }(\beta)\end{array}$ & t-score & Sig.t & Description \\
\hline LOM & 0,026 & 0,249 & 0,804 & Not Sig. \\
\hline GREED & $-0,025$ & $-0,242$ & 0,810 & Not. Sig. \\
\hline
\end{tabular}

Sources: Secondary data was processed using existing SPSS

The result suggests that there is no evidence to show that the love of money and greed has a negative effect that is statistically significant to ethical sensitivity at level $\alpha=5 \%$. This indicates that hypothesis 2 and hypothesis 3 are not supported.

\section{Discussion}

Based on the statistical tests, there was evidence to suggest that the love of money has a positive relation to greed. Theoretically, when one has fulfilled one's primary needs, one is able to survive. However, human beings are not easily satisfied thus, they would always desire to gain more and this is how many people were plunged into greed. A person who loves money will be pleased when he/she owns money and can use the money to do something that he/she wants. When money is acquired, he/she feels comfortable as the person involved would think that money has got him/her the comforts of life. With money, the person can do anything he/she wants hence, he/she tends to use the money he/she possesses unwisely, even to the point of being consumptive. The attributes that money can give him/her is the pleasure to be gained so much so that the person would think that money is everything. Having money is a very important issue for everyone and this is because human beings live in a material world and money is the primary thing needed (Khavari, 2006).

Based on the statistical test, there is no evidence that could show that the love of money has a relation with a person's ethical sensitivity. Likewise, greed too does not mediate the relation. The result of this research is not the same as what Elias (2009) and Tang and Chiu (2003) found where the love of money was found to have a significant and direct influence towards unethical attitudes. This discrepancy suggests that the love of money does not always make a person do unethical things, thus possess unethical attitudes. According to the socio-cultural theory for example, the concept of 'differential opportunity structure', it is stated that delinquency (an activity with a certain purpose: gaining wealth in an illegal manner) will be created when there is discrepancy between the goals demanded culturally among low youth groups (level) with limited chances to achieve the goals in an illegal manner. This is because even though someone loves money a lot, he/she may still consider other things like sins and fines or punishment. 
Islam asserts that human beings are believed to be the caliph, the undertaking of God for the prosperity of life in the world. Man was given more capability than other creatures and the mandate will be held accountable on the face of the divine court. To be able to enjoy prosperity in the world, God created the earth, the sky and everything in it which are destined to human nature to be enjoyed as well as to be evenly shared so that people will prosper economically. Islam does not prohibit the conduct of the exploitation of natural resources in excess but the more a human being does so for himself, the act will only lead to destruction of the universe. From that perspective, it can be concluded that if a person has a strong faith in God, the faith can deter the person from acting and behaving unethically. Another reason why the love of money may not always make a person acquire unethical attitudes is the example mentioned by the Prophet who talks about Qana'ah, which when translated from Arabic means the act of having satisfaction with what we have or accepting whatever that comes to one or is given to one. This means that if a person has a great gratitude to God, the gratitude he/she has will also prevent the person from behaving unethically.

The findings of this is research is in line with what Tang et al. (2003) found, that a person who loves money is easy to achieve the goals effectively and efficiently. The person would also aspire for a better career than those who love money less thus, the love of money can have a positive influence on a person's personal financial optimism (Tang et al., 2005). It was further noted that a person who has much love of money always thinks positively and optimistically about his/her personal gains and private finances (like salary, severance pay, holiday bonus, etc.) hoping that these will increase every year. In aspiring for these to happen, the person will therefore, work harder to achieve these goals whilst paying attention to the ethical values too when doing so. In short, a person who loves money tends to do what it takes to gain financial welfare and good career thus, he/she tends to avoid breaking the law and morality, all of which can affect his career negatively.

The respondents of this research are accounting students who do not have any work experience. They had never acted or behaved unethically in their workplace, such as marking up prices, making fake notes and so on, something which has become quite common at the workplace. These respondents also have no idea what ethical behavior they could be committing should the opportunity arise. They are actually not involved in an actual scenario where they might be tempted to perform unethical acts due to their unethical attitudes. Nonetheless, it is noted that the environment can be a strong influence on a person's personality development. In this regard, as university students, money, in the meantime, may not be as important as when they are in a career, thus, it is possible that as yet, there is no big pressure for them to earn big money. In this regard, their point of view to earn money is still idealistic or even very normative.

University students are considered to be highly educated by the society and this implies that every single thing that they decide to do could set an example for the society. In this regard, it is hoped that every university student in Indonesia could maintain a good reputation by doing good things whether directly or indirectly. This is because university students have a mission to serve which is set good examples for the society to follow particularly in terms of morality and ethics.

\section{References}

Al Qur'an and Al Hadis

Chan, Samuel Y.S. and Leung, Philomena (2006), “The effect of accounting student's ethical reasoning and personel factors on their ethical sensitivity”, Managerial Auditing Journal, 21(4), 436-457.

Charismawati, C. D., \& Yuyetta, E. N. A. (2011). Analisis Hubungan antara Love of Money dengan Persepsi Etika Mahasiswa Akuntansi (Doctoral dissertation, Universitas Diponegoro).

Chen, Y. J., \& Tang, T. L. P. (2006). Attitude toward and propensity to engage in unethical behavior: Measurement invariance across major among university students. Journal of Business Ethics, 69(1), 77-93.

Clikeman, P. M., \& Henning, S. L. (2000). The socialization of undergraduate accounting students. Issues in Accounting Education, 15(1), 1-17.

Elias, R. Z. (2009). The impact of anti-intellectualism attitudes and academic self-efficacy on business students' perceptions of cheating. Journal of Business Ethics, 86(2), 199-209.

Furnham, A. \& Argyle, M. (1998). The psychology of money. London: Routledge. 
Ghozali, I. (2012). Analisis Multivariate dengan Program SPSS. Badan Penerbit Universitas Diponegoro, Semarang

Herzberg, F. (1987). One more time: how do you motivate employees?. Harvard business review, 65(5).

Kasser, T., \& Ahuvia, A. (2002). Materialistic values and well- being in business students. European Journal of Social Psychology, 32(1), 137-146.

Lea, S. E., \& Webley, P. (2006). Money as tool, money as drug: The biological psychology of a strong incentive. Behavioral and brain sciences, 29(02), 161-209.

Luna-Arocas, R., \& Tang, T. L. P. (2004). The love of money, satisfaction, and the protestant work ethic: Money profiles among univesity professors in the USA and Spain. Journal of Business Ethics, 50(4), 329-354.

Mastracchio, N.J. (2005). Teaching CPAs About Serving Public Interest. The CPA Journal 75 (1).

Mitchell, T. R., \& Mickel, A. E. (1999). The meaning of money: An individual-difference perspective. Academy of management review, 24(3), 568-578.

Robertson, C. J. (2008). An analysis of 10 years of business ethics research in Strategic Management Journal: 19962005. Journal of Business Ethics, 80(4), 745-753.

Shaub, M. K., Finn, D. W., \& Munter, P. (1993). The effects of auditors' ethical orientation on commitment and ethical sensitivity. Behavioral Research in Accounting, 5(1), 145-169.

Sloan, A. (2002). The Jury's In: Greed Isn't Good, News Week, 37.

Tang, T. L. P., \& Chiu, R. K. (2003). Income, money ethic, pay satisfaction, commitment, and unethical behavior: Is the love of money the root of evil for Hong Kong employees?. Journal of Business Ethics, 46(1), 13-30.

Li-Ping Tang, T., Shin-Hsiung Tang, D., \& Luna-Arocas, R. (2005). Money profiles: The love of money, attitudes, and needs. Personnel Review, 34(5), 603-618.

Vohs, K. D., Mead, N. L., \& Goode, M. R. (2006). The psychological consequences of money. Science, 314(5802), 11541156.

Wittmer, D. P. (2005). Developing a behavioral model for ethical decision making in organizations: Conceptual and empirical research. Ethics in public management, 49-69.

Wittmer, D. (1992). Ethical sensitivity and managerial decision making: An experiment. Journal of Public Administration Research and Theory, 2(4), 443-462. 